\title{
The Primary Purpose of Presidential Primaries
}

\section{Citation}

Thompson, Dennis F. 2010. The primary purpose of presidential primaries. Political Science Quarterly 125(2): 205-232.

\section{Published Version}

http://www.ingentaconnect.com/content/taps/psq/2010/00000125/00000002

\section{Permanent link}

http://nrs.harvard.edu/urn-3:HUL.InstRepos:9637980

\section{Terms of Use}

This article was downloaded from Harvard University's DASH repository, and is made available under the terms and conditions applicable to Open Access Policy Articles, as set forth at http:// nrs.harvard.edu/urn-3:HUL.InstRepos:dash.current.terms-of-use\#OAP

\section{Share Your Story}

The Harvard community has made this article openly available.

Please share how this access benefits you. Submit a story.

Accessibility 


\title{
The Primary Purpose of Presidential Primaries
}

\author{
Dennis F. Thompson \\ Harvard University \\ Prepared for the Presidential Nominating Project
}

Columbia University, October 23, 2009

Submitted to PSQ 1-25-10

The impulse to make the nominating process more democratic has shaped the debate about party reform throughout its history. The creation of conventions, the rise of primaries, the efforts to make conventions and primaries more inclusive, the case for caucuses, the pleas of small states and large states, and the more recent criticism of front-loading - all have been justified in part by appeals to general principles of democracy, and encouraged by the assumption that more democracy is better.

Both the reformers and their critics claim the mantle of democracy. Yet they have rarely paused to explain what conception of democracy they have in mind, or which principles of democracy they are trying to realize. Political scientists have not done much better. They have usefully described and explained how the process works, and pointed out defects in the system and suggested ways to overcome them. But they have not analyzed the normative basis of their evaluations and recommendations. The editors' introduction to the recent PS symposium simply lists four goals without justifying any of them. ${ }^{1}$ The authors of another recent study in a section on "Unresolved Normative Questions" acknowledge that answering the questions "depend heavily on what one means by democracy," but then conclude that this is "an issue we do not wish to take on."

It is understandable that political reformers and political scientists wish to avoid the hazards of theorizing about democracy. Theorists themselves do not agree about principles of democracy, or even about how to resolve disagreements about them. Moreover, much useful work can be done without invoking comprehensive theories of democracy or engaging in complex normative analysis. But the neglect of theory has a cost. Some important aspects of democracy do not receive the attention they deserve by reformers, critics or political scientists. As a result, the agenda of the study and practice of nominating presidents is at best incomplete and at worst misconceived. The primary purpose of primaries - evaluating the candidates deserves greater and different attention than it usually receives.

\section{THE NEED FOR NORMATIVE THEORY}

When Robert LaFollette made the direct primary a centerpiece of his gubernatorial campaign in 1900, he expressed a principle that has framed the debates about the nominating process ever since: "the sovereign right that each citizen shall for himself exercise his choice by direct vote, without the intervention or interference of any political agency." ${ }^{33}$ On one side of the 
debate (in the spirit of LaFollette's principle), the process is said to be more democratic to the extent that it is more inclusive: that is, to the extent that the party's rank and file have more control over the choice, and those who have control are representative of the party's supporters. This remains the dominant view because the pressure toward inclusion is difficult to resist; greater inclusion in decision making is simply what more democracy means to many people. "Each major step in the development of the nominating process has marked a further obeisance to the doctrine that the will of the rank and file of party membership should prevail." ${ }^{4}$

On the other side, the critics of the movement toward greater inclusion can also appeal to democratic principle. They argue that letting the party leaders have more control is in the interest of voters not only in the party but in the electorate as a whole. The leaders are more likely to choose candidates who will be more competitive in the general election and thus give all voters greater choice. "The sovereignty of the voter consists in his freedom of choice just as the sovereignty of the consumer in the economic system consists in his freedom to trade in a competitive market... Democracy is not to be found in the parties but between the parties." ${ }^{5}$

These contrasting views about the importance of inclusion (how participatory the process should be) played themselves out in the debates about direct primaries, the McGovern Fraser Commission in 1969-70 and more recently in the controversy about the role of superdelegates in 2008. Advocates on each side could claim that they support both values; more participation can produce more competition, and more competition can encourage participation. But the two values do not always go happily together, and when choices must be made, their advocates show their conceptual colors. They give greater weight to one over the other in both their rhetoric and their practical proposals. They are guided by different conceptions of democracy.

The contrasting conceptions of democracy and their different implications present raise important questions that deserve further analysis. Why should parties control the nominating process themselves? (The constitution and the courts send mixed messages about this question, and in any case should not be considered the final authority on the principles of democracy.) If the key principle is participatory, should all primaries be open to all voters?

Are caucuses less democratic because they are less representative, or more democratic because they permit more active participation by those who attend? Is a national primary more justifiable because turnout is higher or are regional primaries preferable because they give citizens more information? On either competitive or participatory conceptions, we should question whether democracy requires equality among the states. Even in a federal system, the primary value is the individual citizen. Fairness to the states is a principle that must ultimately must rest on the value of fairness to individuals.

A more complete normative analysis of the process would try to clarify the implications of these two conceptions, resolve differences if possible, and identify issues that could be illuminated by further research. Rather than pursuing this broader project, I concentrate here 
on only one normative principle - choosing the best candidate - partly because it expresses a goal that has received less attention in the controversies about the nomination process. It is also a principle that in a sense is prior to the others. The primary purpose of primaries is to select nominees; participation and competition are mainly (though of course not exclusively) means to that end. Most significantly, if we focus on that end, we can recognize a further distinctive way in which the process can be made more democratic. The nominating process is more democratic to the extent that it enables voters to select candidates who are committed to the democratic process.

\section{The Character of THE NomineEs}

Neither the familiar conceptions of democracy nor the usual discussions of reforms of the process emphasize this goal because they tend to focus on who makes the choices rather than who is chosen. Participation and competition receive nearly all of the attention. Yet on any conception of democracy or any proposal for reform, the quality of the nominees - more specifically their character - should be a chief concern. It should be especially prominent in evaluating the primary process. It might even be considered the distinctive purpose of the process. By the time the general election arrives, the range of choices has been practically narrowed to two, and most voters decide on the basis of attitudes or views they held before the campaign. In that sense, the nominating process is the last clear chance for most voters to make choices based on the character of the candidates. A key question, then, should be how well does the process allow citizens to judge their character.

The influence of the process on character was recognized more than a century ago by political scientist Henry Jones Ford:

All that the direct primary, or any other political reform, can do is to affect the character of the politicians by altering the conditions that govern political activity, thus determining its extent and quality. The direct primary may take advantage and opportunity from one set of politicians and confer them upon another set, but politicians there will always be so long as there is politics. The only thing that is open to control is what sort of politicians we shall bave. ${ }^{6}$

Ford's comment is repeatedly quoted by contemporary political scientists presumably because it anticipates the view that reforms intended to increase rank and file control of the nomination process usually only result in replacing one elite with another. ${ }^{7}$ Because this smartly cynical observation resonates so strongly with many contemporary observers and political scientists, the other more subtle point Ford made has been neglected. The process may not affect who chooses but it can influence who is chosen - the "sort of politicians we shall have." Ford does not say exactly what alterations in the conditions he thinks affect character of politicians, or what qualities of character are relevant, but he clearly identifies a key question we should ask about the nominating process - how well it reveals the character of the candidates. 
Party leaders do not completely ignore character in choosing nominees or making party rules. But they understandably focus on those aspects of character that serve the interest of the party more than the purposes of the democratic process. They argue about whether it is more important to choose a candidate who is reliably loyal (and appeals to the base) or a candidate who independent-minded (and more attractive to independents and moderates). If they consider the kind of character they would like to see in the other party's nominee, they may prefer to see more vices than virtues; the less admirable the character of the rival nominee looks in comparison with their own nominee, the better.

But from the perspective of the citizen (and the good of the democratic process), the character of the candidates of both parties are equally important. Citizens who will have to live under the government of one or the other of the nominees should care as much about the nominee of the party they oppose as the nominee of the party they support. Unless they can be confident that their preferred candidate will win, they should want both parties to nominate the best possible presidential candidate. The importance of considering the character of both nominees can be further brought out by distinguishing two perspectives on the democratic process - that of voter and subject. As voters, citizens may and typically should express their partisan preferences. As subjects, citizens should and typically do accept the authority of their elected leaders. (The basic distinction comes from Rousseau, but in his version the citizen as sovereign (the voter) should decide on the basis of the general will, not factional interests. ${ }^{8}$ ) It is the perspective of a subject that is most relevant in the design of the nominating process (and the electoral system as a whole). As subjects, we should seek a process that produces leaders of good character whatever their partisan views and political positions. That is why we should want the nominating process of both parties to encourage assessments of the character of nominees, and on the basis of criteria that all citizens could accept.

However, it will be immediately objected that any criteria for evaluating character surely depend on your partisan preferences and policy views. You may value loyalty most of all, and I may favor boldness; even if we both think both are important, you may put more weight on one than the other. Or both of us may prefer a president who shares our policy views even if his character falls short. Judgments about competence or intelligence seem to be similarly tied to views on policy. Except for a few minimal qualifications (the nominee should be able to state truthfully "I am not a crook"), any distinctive set of qualities is arguably partisan or at least contestable. Loyalty may be associated with support for partisan purity, for example; boldness, with progressive reform. Citizens should not be expected to agree on any set of qualities, so the objection goes, regardless of which party they belong to or which candidate they favor on policy grounds.

The objection may partly explain why theorists and reformers tend to focus on the participatory and competitive criteria for evaluating the nominating process. Even political scientists who recognize that the quality of nominees is relevant to assessing the process end up using criteria that are essentially those of the participatory and competitive conceptions. 
For example: "quality candidates should be representative of their party and able to win in the general election;" the process should "level the playing field at the beginning in terms of money and access to voters and media." ${ }^{\prime 9}$ A process that satisfied these criteria might well produce better candidates or at least reduce the chances of those whose support depends on only money and prior recognition. But these criteria are at best indirect ways of evaluating whether the process enables citizens to assess the character of candidates. They remain neutral on what is to count as quality - what kind of character the process should seek - and therefore give little guidance in evaluating the extent to which the process provides opportunities for assessing the right kind of character.

\section{THE CHARACTER OF CANDIDATES}

Is it possible to find a more substantive principle or set of criteria that could serve this purpose? I propose that we consider a principle that would judge the process by how well it shows whether candidates themselves respect the democratic process. The idea is that the process can be democratic not only in how it treats those who choose, but also in what it reveals about those who are chosen. The principle affirms that a process is in this sense more democratic to the extent that it enables citizens to judge a candidate's commitment to the democratic process, or lack thereof. In addition, it suggests that the process is more democratic to the extent that it enables candidates to strengthen that commitment during the campaign. On this approach the other principles such as participation and competition play a different role: how the candidates deploy the principles become part of the test of their character.

What should we look for in judging a candidate's commitment to the democratic process? I suggest that we should care most about those qualities make up what may be called constitutional character. This refers to the disposition to act, and motivate others to act, according to the principles that constitute the democratic process. It does not refer primarily to personal character. The personal vices that too often interest the media-most often sexual misconduct - are rarely relevant, or not as relevant as the attention they get implies. Private vice combined with public virtue is not uncommon in the character of politicians. ${ }^{10}$

No doubt there are many personal qualities that would help a president use the democratic process as well - for example, courage, compassion, loyalty. But even these take a different form in public than in private life. Loyalty to friends, for example, is more likely to be a vice than a virtue in governing. Constitutional virtues are different: they are specific to public office, either because they take a different form in public life or because the occasion for their exercise does not arise in private life. ("Constitutional" does not refer to the document itself, but to the broader understanding of what is required of officials for the democratic process to work well in the U.S.) Elsewhere I have discussed the content of these virtues and episodes in which presidents showed or failed to show constitutional character. ${ }^{11}$ Here I briefly describe only four of those virtues for the purpose of illustrating how the primary process can reveal 
constitutional character. None is morally or politically neutral, and interpretations of each may well provoke partisan and ideological disagreement, but their essential content should be acceptable to anyone who is committed to the democratic process.

Capability for Collaboration. An essential prerequisite of the democratic process is the existence of a vigorous opposition, which in turn requires a disposition not only to tolerate but work with political opponents. ${ }^{12}$ A collaborative leader facilitates that compromise that a robust democratic process requires. This virtue includes the willingness to engage with diverse groups of citizens, to respond constructively to criticism, rise above factional interests, and actively to seek opportunities for cooperation with their opponents. Its opposite is revealed in the extreme partisanship and political polarization of the kind that has marked national politics in the U.S. in recent years. In the primary, this vice is most clearly revealed when candidates put their own will to win ahead of the good of the party, and when they direct their appeals only to a narrow range of interests.

Sense of Responsibility. Like leaders of any large organization, responsible presidents should be accountable for the failures of their subordinates. They should "take responsibility" for major mistakes - but not in the ritualistic way that this practice is commonly carried out. ${ }^{13}$ Taking responsibility does not show a sense of responsibility if no consequences follow for those who take it. Constitutional character calls for a sense of responsibility that results in effective actions before and after the "taking." The actions may include the dismissal of high level subordinates, independent investigations, and institutional reforms to prevent similar mistakes in the future. More generally, responsible presidents give reasons for their actions and omissions. In a primary a candidate can demonstrate this virtue by taking responsibility for the failures of staff, and by publicly justifying decisions the campaign makes.

Respect for Due Process. As the presidency has grown more powerful, presidents have become bolder in pursuing their ends with means that may formally follow the constitution but flout its spirit. They are tempted to use executive power in ways that disregard established procedures, and usurp the rights of others. It is therefore all the more important that the president have a respect for due process in the broadest sense. This virtue includes a disposition to follow the spirit as well as the letter of procedures that have been agreed upon, respect the rights of legitimate authorities, support fair processes for resolving disputes, making changes and engaging in competition. In a primary, candidates can show their commitment to process by abiding by the party rules, or by challenging the rules in a manner that is generally regarded as fair. The strategies favored by their campaign managers often provide a telling clue: do they welcome fair play and open competition, or do they prefer dirty tricks and devious intrigue?

Commitment to Candor. Candor is the pre-eminent virtue of the democratic process because it is the pre-requisite for discovering the other virtues and vices of the president and his associates. We cannot hold officials accountable for these other vices and other misconduct if they deceive us about what they are doing. But even with respect to the virtue of candor, we 
still need to be selective in what we require of leaders. One reason to be discriminating is that presidential deception is occasionally justified, and presidential evasion sometimes required. Constitutional character does not abjure either absolutely, and therefore includes the capacity to discern when each is and is not warranted. In primaries, blatant lies, at least those that can be proved, are probably rare simply because they are readily exposed, usually to the candidate's disadvantage. Other failures of candor are more common and perhaps more telling: for example, vagueness or equivocation on a controversial issue. Those can be all too readily detected in some primary campaigns.

Some may question whether we can learn much of anything from what the candidates do and say during a campaign. Candidates have incentives to appear at their best and to avoid uncontroversial positions on issues. They may behave quite differently and take different positions once in office. They may say "read my lips: no new taxes" in the campaign and then support a tax increase in office. Indeed, it is reasonable to ask whether campaigns are a good way to select leaders at all. We do not use campaigns or even elections to choose leaders of most of the other large private institutions that govern our lives-corporations, hospitals, universities, the media. The same is true of appointments in government and other public institutions where the competence of the leader is critical. Perhaps it would be possible to hold elections without campaigns. A citizens' search committee that would vet the candidates, narrow the field, and make recommendations to voters might well produce more accurate and useful information than do campaigns as we know them. But the legitimacy of such a committee (or any other body serving in this role) would always be in doubt, and to that extent so would the legitimacy of the leader who emerged from this process.

For good or for ill we have campaigns, and we have to make the best of them. Although they may not be the most reliable predictor of performance in office, they can provide some useful indicators if properly structured. They may be more useful for evaluating the character of candidates than their positions on issues. Positions on issues can and sometimes should change, as circumstances change and as new issues arise. Character is more stable and less likely to change in office. Furthermore, candidates inevitably reveal aspects of constitutional character in how they run their campaigns - the kind of people they appoint, the style of management they adopt, the attitude they take toward opponents. Running a campaign is not of course the same as governing, but it is more like governing than taking positions on issues. To the extent that primary campaigns can be made better instruments for testing constitutional character, they could become a more useful device for evaluating candidates.

\section{THE Character of THE PROCESS}

What kind of primary process would better enable citizens to assess, and candidates to demonstrate, constitutional character? The most general requirement is that the process should provide opportunities for learning by both voters and candidates. It should allow and 
encourage preferences to change over time. This important point about the dynamic potential of primaries has been lost in the controversy about alternative explanations for candidates' success in primaries. The dominant view among political scientists has been that momentum is the major factor (at least if one of the candidates is relatively unknown). For example, if a candidate does "better than expected" in Iowa and New Hampshire, he gains disproportionate media attention and financial support, which translates into ultimate victory. ${ }^{14}$ More recently, some scholars have challenged this explanation, suggesting that endorsements from major groups aligned with the party are more important in most races. ${ }^{15}$

The focus on the question of whether the party elite or the rank and file are more influential has obscured a more fundamental property of the primary process as it currently exists. Stretched out in time and dispersed in space, primary voting permits and even encourages voters to change their preferences. Whether under the influence of the media, party elite, or their own deliberation, voters at each stage can take into account information and opinion generated at earlier stages and in other places. Although Bartels put forward what has been called the "canonical" statement of the momentum explanation, ${ }^{16}$ he was just as concerned to emphasize the dynamic nature of the process, specifically to challenge the assumption that preferences are fixed (a view he attributed to classical public choice theory). His most general aim was to bring out the implications of the fact that voters' preferences change during the primary campaigns in response to other people's preferences and opinions (including general expectations about candidates' chances). In his view, the most important normative implication ("the unresolved normative issue") is whether the collective choice of the nominee should follow the "unsocialized preferences" (opinions that exist before the process begins) or "socialized preferences" (opinions shaped by the interactions during the process). ${ }^{17}$ Any campaign will socialize preferences to some degree, but the more normative weight given to socialized preferences, the more important it is that the process provides opportunities for the right kind of socialization. The character-based principle I am proposing for assessing the process implies that the socialized preferences should have greater weight, and therefore that the dynamic properties of the process - the opportunities for the right kind of preference change - are critical to evaluating it.

To allow for such preference change, the process should be sequential rather than simultaneous, and intervallic rather than concentrated. A primary process should be designed so that candidates compete in multiple contests in different states and regions over time and so that the individual primaries are sufficiently separated in time to permit political learning. Such a process has a number of benefits, but here I concentrate on those that bear on the assessment of constitutional character.

\section{Simultaneous V. SeQuential PRIMARIES}

Public opinion consistently favors a single national primary. Some political scientists agree. ${ }^{18} \mathrm{~A}$ national primary would have important advantages. It would treat all states equally, increase 
turnout, and reduce costs. All voters would have the same information as in the general election (to the extent that the latter is simultaneous). ${ }^{19}$ But the reform favored by most political scientists and most politicians is some version of sequential regional contests. There are many variations (the Texas, Ohio, Michigan, Delaware Plans and the proposal of the National Association of Secretaries of State).${ }^{20}$ All are designed to give more states and more interests a greater opportunity to influence the outcome.

The most obvious political appeal of the plans is that they treat more states and more groups equally. But normative significance of that feature is less clear: states and groups are not individuals, and the effect on equality of citizens is ambiguous. The more definite normative value lies in the sequential character of the process. A series of primaries provides opportunities for the candidates to demonstrate their commitment to the democratic process, or lack thereof. They have more opportunities to be tested, and in a greater variety of settings. Social scientists have often cited information gains as a benefit of sequential elections, and most of these plans would contribute to that goal as well. ${ }^{21}$

The sequential property is no less important for learning about and developing constitutional character. Positions on issues can in principle be presented and debated before a single election, and indeed voters might even be more likely to absorb the information if they have to pay attention to a single election rather than a series. But character is not something that can be presented in a statement or a pledge. It has to be observed in context, and it is more effectively observed in a variety of contexts over time. This is all the more true of constitutional character because its virtues are process-related, and can be more clearly revealed in a process that is ongoing. Thus the character-based principle adds a further consideration in favor of sequential primaries. Even if it points toward the same conclusion as some other principles suggest, the perspective it provides is distinctive. Because it is not based on fairness to states or general information gain, it directs attention to specific features of the process that other approaches based on other principles tend to neglect. It emphasizes the need to create opportunities for testing the candidates' commitment to the democratic process.

Consider the constitutional virtue of candor. Complete candor is hardly an absolute rule in a candidate's playbook. Some evasion may be competitively necessary and even justified. Yet some candidates seem to do better than others in navigating a course between self-destructive outspokenness and devious equivocation. Political scientists have tried to explain why some candidates are more evasive or vague than others. ${ }^{22}$ Carter in 1976, Bush in 1980 and Hart in 1984 were more often charged with "fuzziness" (deliberate issue ambiguity) than were other candidates at the time. The best explanations appear refer to the strategic advantage that equivocation gives less well known candidates. At first voters have less information about these candidates and their positions on issues, and can "project" their own views on to the candidates, as long the candidates do not say anything too specific. But as the process continued and the emerging contender is forced to become more explicit, he begins to "pay a price for his new familiarity in the form of more critical, more realistic, scrutiny of his 
issues stands. ${ }^{23}$ In this way, a sequential process, spread out over time and space, encourages a kind of candor, or at least discourages a campaign of permanent equivocation.

The capacity to appreciate and communicate with citizens with diverse interests - an aspect of the collaborative virtue — can also be more readily observed in a sequential primary. The President is president of all the people, and the candidates should be prepared to engage with citizens from all regions and groups. It might seem at first that a national primary would be a better test of that capacity, but national campaigns tend toward homogenization; they are more likely to emphasize issues and appeals that are held widely and downplaying regional and special interests. They usually reveal less about how leaders will deal with particular interests, both those that merit attention and those that do not. In a series of primaries in different states (even if front-loaded) candidates confront particular interests, and all voters - not only those in the state in question - can see how they deal with the diversity.

The issue of ethanol, which excites Iowans more than most other voters, has given candidates a chance to show how they handle particular interests. Facing the Iowa caucuses, both McCain and Hilary Clinton abandoned their long standing opposition to ethanol subsidies. They both provided explanations, which were not entirely without merit. Both said that circumstances had changed, and the nation needs to exploit every possible source of renewable energy. However, expert opinion, which generally takes a less favorable view of the potential of ethanol, had not changed, and many voters were understandably suspicious. The point is not that a caucus or primary in one state can better expose political hypocrisy, only that it can better test candidates' capacity to justify their positions when they face audiences with different and conflicting interests. The contrast between particular and general interests is usually less vivid and more easily finessed in a national campaign.

In a sequential process, a candidate has the opportunity to decide in which states to compete, and the decision itself tells us something about the willingness to engage with diversity. Does a candidate decide to compete in a variety of states or only in friendly states? Al Gore in 1988 and Rudy Giuiliani in 2008 calculated that they could do better in the later primaries where voters' views more closely matched theirs, and therefore decided to avoid Iowa and New Hampshire where voters' attitudes seemed less sympathetic to a Southerner or a big city mayor with culturally liberal leanings. ${ }^{24}$ As it turned out, skipping these tests not only reflected poorly on their constitutional character but also cast doubt on their strategic judgment. Here as in many cases, character and judgment go together.

\section{CONCENTRATED V. DisPersed PRIMARIES}

One of the most troublesome trends in the primary process is what has been called front loading - the scheduling of more primaries soon after the formal opening of the nomination process with the result that the nominee is effectively chosen by the middle of March. ${ }^{25}$ The Obama-Clinton contest in 2008 is the only recent exception, and it did not put to rest other concerns about front-loading, such as the "very high fundraising entry fee" and the premature 
elimination of "serious and well-qualified candidates."26 Many people also complained that this primary went on too long, testing not so much the character of the candidates as the patience of the public. But the problem is not the length of the campaign. A shorter process would not be as useful for assessing constitutional character. The problem lies in the temporal structure of the process - concentrating rather the dispersing the primaries. The primary process may be sequential but if the contests are concentrated the process is for several reasons less suitable for assessing character.

First, a front-loaded concentrated process increases the influence of the "invisible primary," the period before the first primary when candidates raise funds, collect endorsements, take polls, and recruit consultants and staff, and generally try to become better known, preferably as one of the front runners. ${ }^{27}$ The candidates' success in this "primary" often substantially determines their chances in the real primaries that follow. If the real primaries all take place at the beginning of the season, this invisible primary becomes the campaign that matters. The problem is that it is a campaign that most voters and even the media do not see. Whatever the invisible primary could reveal about character remains hidden from most voters.

Second, the intervals between the primaries must be sufficiently long to allow both voters and candidates to absorb the new information that the process generates. One calculation suggests that for voters at least three weeks is necessary. ${ }^{28}$ Voters need time to process any kind of information, but the need is even greater for information about constitutional character. Candidates' attitudes toward the democratic process can often be evaluated only by combining information from several different episodes (a process by its nature is continual). Interpreting these multiple data points takes time.

Third, a dispersed process gives candidates a chance to correct their earlier errors, providing a more balanced view of their character, and perhaps even allowing them to learn lessons that may influence how they govern. During the early part of the campaign in 2007, Obama was showing a tendency to blame staff for campaign mistakes. When he failed to appear for a key meeting with union leaders before the New Hampshire primary, he told the organizers that his staff had made a mistake in scheduling. A month later he blamed staff for a derogatory memo about Hilary Clinton, and for another memo about Clinton's allegedly racial remarks that was circulated to South Carolina media outlets. ${ }^{29}$ Some observers pointed to an "emerging pattern" of avoiding responsibility. ${ }^{30}$ Finally in January, during one of the debates, Obama took responsibility himself: "And it is my responsibility to make sure that we're setting a clear tone in our campaign, and I take that responsibility very seriously, which is why I spoke yesterday and sent a message in case people were not clear that what we want to do is make sure that we focus on the issues. ${ }^{31}$ By the time he was in office, he had learned the lesson, at least a lesson of how to talk about responsibility. After his nominee for Secretary of Health and Human Services was forced to withdraw because of ethics problems, Obama said: "I consider this a mistake on my part and one I intend to fix and correct and make sure we don't screw it up again." ${ }^{\prime 2}$ In all of these incidents, the staff or associates made the mistakes in 
the first place, but an important requirement of a constitutional leader is the willingness to take responsibility for the mistakes of his subordinates. Taking responsibility should not be merely rhetorical but must be accompanied by effective action such as changing management practices or making difficult personnel decisions.

\section{Close EnCOUNTERS: IOWA AND NEW HAMPSHIRE}

In a sequential primary, even with appropriate intervals between each contest, some states will go before others, and will have a greater chance to influence the race at critical moment (for example, by creating momentum for an underdog, reducing the chances of the favorite, setting the agenda for later contests). Why should Iowa and New Hampshire always enjoy this privilege? Neither state deliberately decided to go first for strategic reasons. New Hampshire has held the first in the nation primary since 1920, but no one paid attention until 1949 when delegates were permitted to identify with one of the candidates, initiating the first presidential preference primary. Even then, other states did not care much because the early contests did not have significant effects. Iowa's caucuses became the first event on the primary calendar in 1972 simply because of the time needed to go through the state's multi stage selection process leading up to the convention. But after Jimmy Carter's unexpected success in 1976, which was made possible only by his early victories in these first two states, the complaints about their privileged position grew more clamorous.

Critics argue that granting any state this privilege is unfair, and that because these states are unrepresentative of the nation as a whole, their influence biases the agenda and potentially the final result of the campaign. Issues of greater interest to urban voters and minorities, for example, are likely to receive less attention. The caucuses themselves are also said to be unrepresentative because only a relatively small number of people participate (typically those who are highly motivated and have more flexible schedules). ${ }^{33}$ Although there were efforts to dethrone the Iowa and New Hampshire (the Carter White House even supported one of the first and most serious attempts), they have doggedly held on to their position. Their politicians cared more about being first than about losing delegates (the only penalty the national parties have at their disposal). They simply cared more about their position than did the politicians in other states, and were willing to play hardball to keep it. As one commentator put it: "What they do, in effect, is blackmail the candidates." ${ }^{34}$

Is there any reason other than the "pragmatic argument" ("just concede the inevitable") to continue to let these states go first? From the perspective of participatory democracy, its distinctive advantage is that it facilitates face to face politics with genuine interactions instead of the media driven politics typical in the other states. New Hampshire does not have official caucuses but the informal events that have become common in the state serve a similar purpose. Even if (as some evidence indicates) most voters in both of these states still get most of their information from television, ${ }^{35}$ they have access to reports about the discussions in the caucuses. Voters do not have to be present to benefit from what can be 
learned from the caucuses. Even voters in other states can vicariously profit from this information, and from any lessons the candidates themselves learn. The most comprehensive recent study of the Iowa caucuses concludes that they do in fact facilitate "the give-and-take of retail politics," encouraging real debate on the issues, and forcing candidates to build grassroots coalitions. The caucus process evidently limits the impact of negative campaigning and the influence of advertising dollars. ${ }^{36}$ Furthermore, another recent study shows that Iowa voters are in many respects actually typical of the rest of the electorate in many respects. ${ }^{37}$

These general advantages translate into specific contributions to the task of judging constitutional character. Voters and vicarious participants are probably better able to assess character in face to face relations than in more distant, mediated encounters. Psychological studies generally find that people are not very good at detecting deception, certainly not as good as they think, but to the extent that they are successful, they take advantage of a wider range personal cues, including nonverbal behavior. ${ }^{38}$ If people are better able to assess truthfulness in personal interactions, then caucuses and similar settings would appear to be more useful for assessing the constitutional virtue of candor. It is reasonable to assume that candidates are more likely to reveal a tendency to shade the truth in such settings than in media presentations, which are more vulnerable to manipulation and less open to interaction among the participants. Caucuses can be manipulated too, but they can be more readily modified in ways that could serve as better tests of candor.

The implication is not of course that all states should now institute caucuses. It is simply that those states that have a traditions of this kind of "retail" politics should be allowed to maintain their potentially influential place in the primary process. The present calendar is not the only way to preserve that advantage, however. The Delaware Plan (favored by the RNC in 2000 but defeated at the last minute), which ensures that small states would always go first, may serve the purpose as well. ${ }^{39}$ Nor are in-person meetings always necessary. The key factor is interaction, and this can be accomplished virtually. Some recent experiments with internet communication between constituents and their representatives show that meaningful dialogue can be achieved through virtual town meetings. ${ }^{40}$

\section{Playing By the Rules: Superdelegates, Robots and Premature Primaries}

The disputes that periodically erupt about the rules of the primaries and conventions offer opportunities for insight into the candidates' attitude toward democracy, specifically their respect for due process in the broad sense. Most of the time the public does not pay much attention to these disputes but they can be important not only because how they are resolved

affects the outcomes, but also because how they are handled by the candidates opens a window on constitutional character. In the most recent Democratic primary, a dispute about the rules did move to center stage in the campaign. Two rules that had been of interest only to party insiders - the provision for appointing superdelegates to the convention, and the rule for 
imposing sanctions on states that scheduled their primary earlier than allowed by the national party - attracted wide attention as the competition for delegates intensified.

Representing about 20 percent of the votes at the convention, super-delegates gain their seats by virtue of their current or former positions as party or elected officials. Some are also appointed by the state parties during the primary. ${ }^{41}$ None may be pledged to any candidate in advance. The role of superdelegate was created in 1982 by the Hunt Commission partly in reaction to the effects of previous rule changes that had been intended to make the convention more responsive to the results of the primaries. In the eyes of the party leaders, the changes had succeeded all too well, and were producing less electable candidates like McGovern who appealed more to the base of the party than to the general electorate. The official purpose, as stated by Chairman Hunt, was more general: "to give our convention more flexibility to respond to changing circumstances and in cases where the voters' mandate is less than clear, to make reasoned choice. ${ }^{\prime 2}$ Party leaders, the commission believed, would have more (and more up to date) information and experience, and would therefore be better judges of who would make the better candidate, which in practical terms meant the candidate who would be strongest in the general election. A few party leaders, notably Jesse Jackson, objected that the role of superdelegates is an undemocratic device because it allows an elite to overturn the will of the party rank and file. ${ }^{43} \mathrm{He}$ had a point: he was appealing to the principle that the more inclusive body should have the ultimate authority, a principle that Obama would also later invoke. But his objection was mostly ignored, and the issue remained dormant because, as the primaries played out from 1984 to 2008, the front runner's lead was great enough early enough to make the superdelegates irrelevant.

All that changed in 2008. By mid February 2008 when nearly 70 percent of delegates had been pledged to either Obama or Clinton, the difference between their totals was slim. Clinton supporters saw the superdelegates as essential to their victory. "I believe that the superdelegates should do the same as any other delegate or voter, which is to determine who they believe will be the best President." ${ }^{44}$ She was following the rules in the sense that she was appealing to the original understanding of the purpose of super-delegates. "Best candidate for president" would have been a more accurate description of the original aim, but on either interpretation she was invoking perfectly legitimate democratic principles, either that parties should choose the person who would make the best president for all citizens, or the person who would make the most competitive candidate in the general election. For his part, Obama insisted that the will of the majority of voters should prevail, not the decisions of an unelected elite. This was a version of a principle of equal votes that Jackson had earlier invoked and Clinton would soon use for a different purpose. If the Clinton attempt succeeded, it would be, as one Obama supporter put it, "a coup by superdelegate — the overturning of the popular results by the party elite." 45

Both candidates were appealing to valid principles of the democratic process, but in this instance Clinton had the stronger case on the merits. If there are good democratic reasons 
on both sides in a dispute about an ongoing process, the more justifiable position is the one that has been adopted in advance. That is part of what respect for a process means, part of the broader idea of democratic due process. If Obama's supporters had argued only that the superdelegates should use their legitimate discretion to conclude that all things considered the primary results should prevail, he would have been on stronger ground. Although some of their complaints could be read in that way, the campaign usually stated the objection quite generally, claiming that the use of any discretion by super-delegates is illegitimate.

Playing by the rules is an important part of due process, but it does not mean that rules are desirable only because they have been agreed to. In 1976 the Democratic Party adopted what was later dubbed the "robot rule" requiring delegates to vote for the candidate to whom they were pledged at least on the first ballot at the convention. ${ }^{46}$ Because the robot rule was agreed to in advance, delegates were obligated to observe it until it could be changed. But it is not an appropriate rule for the party or for the democratic process. The dynamic character of a campaign - the value of allowing voters and candidates to change their minds in response to changed circumstances and new information - points to the need to give delegates some discretion. The party leaders recognized this value in 1982 and softened the rule to allow delegates to vote "in all good conscience." ${ }^{\circledR 7}$ This small change served a larger principle. Although the change was not expected to have much if any practical effect, the principle still at least symbolically reminds candidates that they should not treat delegates as "automata that mechanically record the preferences expressed by voters at home," ${ }^{8}$ but as autonomous party members whose loyalty must be won and kept by giving reasons that respond to changing circumstances and new information. It expresses the importance of the constitutional virtue of responsibility - here a commitment to accountability that goes beyond the expectation of loyalty. The symbol lasted until 2012. The party's Democratic Change Commission, taking a more mechanical view of what democracy requires, recommended that super-delegates no longer have this discretion. The Commission sought to "make the process more democratic by converting unpledged delegates to a pledged status that allocates them based on the results of statewide caucuses and primaries while continuing to recognize the important role these leaders play within our Party." ${ }^{49}$

The other striking controversy about the rules in 2008 was also intensified by the closeness of the contest. In 2006, to prevent a race to the front of the calendar, the Democratic National Committee had stipulated that only four states could hold a primary event before February 5. (In a token gesture toward diversity, Nevada and South Carolina were allowed to join New Hampshire and Iowa in the early contests.) If a state violated this rule, it would lose 50 per cent of its delegates at the convention. Also for the first time, candidates who campaigned in the offending state would lose any delegates they might win there. ${ }^{50}$ Michigan and Florida deliberately violated the rule, and selected a majority of delegates for Hillary Clinton. As the distance between the delegate counts narrowed, Clinton's supporters realized that they could not win without Michigan and Florida. They demanded that the rule be waived 
so that all the delegates could be seated. They appealed to a legitimate democratic principle of political equality, using the slogan familiar from the recount dispute in the 2000 election in Florida - "count every vote."

The appeal is indeed one that any good democrat could embrace; as a principle of equal votes it should have a prominent place in any democratic theory. Obama had invoked a variation of it in objecting to the potential intervention of superdelegates. But it was misplaced in this dispute about seating the delegates. Its appropriate place is in the process of rulemaking, where what counts as a vote is determined. Clinton would have had a more credible case had she raised her objection before or after the campaign. The Obama campaign had the stronger argument: the rule was clear and fair, and had been agreed to by all parties in advance. Any apparent unfairness arose only because two states pushed ahead of the others in violation of rules to which all had consented, and now one candidate was taking advantage of the violation.

By the end of May, the party leaders reached a tenable compromise (all the delegates from Florida and Michigan would be seated, but given only one-half vote each, and Obama would be given four extra votes from Michigan). Obama found it acceptable; it left him only 66 delegates short of the nomination, with three primaries to go. Clinton supporters objected, and threatened to take the issue to party convention. But in the end both candidates accepted the compromise and in doing so, showed their willingness to put aside their own personal feelings and lingering animosities to work together for the good of the party. The cause in this case was partisan, but the collaborative spirit suggests a character trait that may be transferable to the larger cause of promoting the democratic process.

It is tempting to interpret the dispute about the rules as simply another example of politicians' exploiting whatever principles serve their political interests at the time. Clinton appealed to a principle of equal participation when it served her in the dispute about seating Florida and Michigan, but was willing to set aside a very similar principle that would have denied a decisive role to the superdelegates. Obama favored equal participation when he was winning the primaries and caucuses, but was less enthusiastic about applying it to the participation of Michigan and Florida voters. The story is similar in most of the rules fights in both parties: candidates and their supporters fight for the rules that they expect to give them strategic advantage. ${ }^{51}$ This is a conventional view of politics, and it is instructive as far as it goes. But as a general interpretation, it misses two important more subtle aspects of political conduct.

First, in this case the candidates made principled appeals, and the principles were not only plausible but referred specifically to the democratic process. The candidates did not argue merely that they are the best candidate, more in tune with the party's program, and better able to provide the leadership the party and nation needs. They made these substantive claims of course, but they also recognized that to deserve the nomination they had to win in a process that is fair, that they had to show respect for the fundamental principles of democracy. In this 
way, they demonstrated their commitment to due process in the broad sense. More generally, to the extent that candidates make valid process arguments, they shape not only the current but also future campaigns. They create precedents and commitments that may have force in subsequent controversies, including those that they may face in office if elected.

Second, in controversies in which there are reasonable claims on both sides, as in this episode, the candidates have an opportunity to demonstrate their capability for collaboration. Even when the compromise is in their long term political interest, as Clinton may have calculated in this case, the timing, style and attitude candidates exhibit as well as the content of the compromise they accept can reveal something about this constitutional character trait. If as is perhaps more often the case, the claims of one of the candidates is not reasonable, the other candidate should not be expected immediately to accept a compromise, but can demonstrate this constitutional virtue in a different way, by resisting the temptation to respond in kind, remaining open to an opponent's overtures, and looking for new alternatives that might bridge the differences.

Some of the most revealing conduct occurs not in the open violation of formal rules but in the disregard of informal norms of campaign practice. When candidates resort to dirty tricks, or refuse to condemn such practices, they give voters a reason to doubt their commitment to due process. Dirty tricks are especially tempting when a candidate who has been a front runner runs into trouble, as Bush did in 2000. Although starting strongly as the clear favorite of the party insiders, he lost New Hampshire to McCain. As he went into the South Carolina primary, the stakes were high. The contest there produced one of most notoriously dirty campaigns in recent history. Bush supporters spread false rumors about McCain, suggesting that he had fathered a black child, and that his wife used illegal drugs. Although no direct connection to the Bush campaign was ever proven, Bush and his aides never publicly attempted tried to stop the scurrilous attacks. Bush was present himself at one event when a speaker claimed that McCain did not care about veterans. When McCain tried to defend himself, the Bush campaign managed to portray McCain as the negative campaigner. ${ }^{52}$ Bush's tactics could have served as an early warning of the Rovian machinations to come. The conduct of the campaign in this respect foreshadowed some of conduct of the Bush White House. But McCain was not able to seize the opportunity to make this campaign moment a test of constitutional character, and therefore neither were the voters. In 2004, in the same state, he failed - by his own admission - another test of constitutional character, equivocating on the issue of the removal of the Confederate flag from the Statehouse. ${ }^{53}$

\section{The Value of THE Horse Race}

No criticism of campaigns has been more common than complaints about "horse race" coverage ${ }^{54}$ In general election campaigns, the media devote more time to the competition than to the content in the campaigns. ${ }^{55}$ This imbalance is probably more common in primaries than 
in general elections because the differences among the candidates on the issues is less. ${ }^{56}$

Contrary to the conventional criticism, horse race coverage can make a positive contribution to the democratic process. The right kind is useful in assessing the constitutional character of candidates, and especially useful in a primary where policy differences are less salient. To see its potential value, we need to distinguish several different types of horse race coverage - what may be called strategic, predictive, and motivational. The first two can be valuable if conducted in the right way; the third is more likely to be detrimental to the process.

From the strategic type, which describes the plans and techniques of the campaigns and evaluates their relative success and failure, voters can learn something about the character of the candidates and their staff. How the candidates and their managers deal with opponents, respond to negative advertising, handle disputes within the campaign organization are all relevant to assessing constitutional character. Compared to reports on issue positions, stories about how the candidates make their strategic decisions may provide better indicators of the stable inclinations of the candidates and their associates. Because circumstances change, issue positions can and often should change in office, but the attributes of character revealed in strategic decisions usually persist. Whether candidates and their managers act as if winning is the only consideration or pay some attention to the needs of the democratic process, whether they respond to unfair attacks in kind or try to rise above them, whether they care about accuracy or only about what they can get away with - these and similar indicators are relevant for assessing constitutional character. Strategic decisions can be especially instructive about a candidate's collaborative inclinations. In 1980 Reagan had built up strong support in the conservative base of the party, and might have won the nomination without reaching out to moderates. But he worked to "reposition himself not as the factional favorite of GOP conservatives but as the 'natural standard bearer' for Republicans of all stripes." ${ }^{57}$ Although the moderates were suspicious, Reagan in office continued to demonstrate an interest in collaboration, even while steering a distinctly conservative course on most policies.

Predictive accounts cover which candidate is ahead, why voters are supporting the candidate, and whether the candidate is likely to keep the lead. Like strategic accounts, this type of coverage can contribute constructively to the dynamic quality of the campaign by providing voters and candidates with information that allow them to change their minds and adjust their plans. Undecided voters can learn how people in circumstances similar to theirs intend to vote. To the extent that the intentions reflect and the stories refer to assessments of constitutional character, accounts of the changing fortunes of the candidates give voters (and even candidates) valuable information. However, predictive coverage does not always take this form, and is therefore a less reliable tool than the strategic type. More commonly, the predictive approach leads to coverage that gives much greater attention to candidates who do better than expected, regardless of their actual standing. "The history of primary campaigns is dotted with famous examples of losers treated like winners (Eugene McCarthy in New Hampshire in 1968) and winners treated like losers (Edmund Muskie in New Hampshire in 
1972). ${ }^{\prime 58}$ Neither the balance nor the content in this kind of coverage is helpful to voters who would wish to assess the character of the strongest candidates.

The third type - motivational coverage - is the most problematic. It generally merits the opprobrium that the conventional criticism lays on all horse race reporting. In this kind of coverage, journalists speculate about what moves the candidates to take certain positions or adopt certain strategies. They do not take the candidates' claims at face value, but look for the "real" motives that the candidates are reluctant to reveal. ${ }^{59}$ They assume that the motives are always self-interested - political" in the perjorative sense in which nothing matters except competitive advantage. This kind of coverage tends to reinforce the cynicism of voters and decrease their interest in politics. ${ }^{60}$

The motivational type of coverage also reinforces the least admirable inclinations of commentators and journalists. To write about motives in this way requires less thought than most other kinds of analysis. The journalist does not have to try to analyze the public reasons, which are usually complex, or the candidate's actual conduct, which is often ambiguous. Journalists are not always wrong to be cynical, but they are usually wrong to be superficially cynical, which is the default attitude of too many. The motives of nearly all politicians are mixed, and some self-interested motives move them toward, not only away from, the public interest. To point out that a politician is politically motivated does not show much if anything about constitutional character. Self-interested motivation, especially if excessive, may be a sign of other character deficiencies: for example disregarding rules that are not to your advantage. But even here the focus should be on these deficiencies, not the motives. Even when motives are relevant for assessing constitutional character, they deserve more discriminating coverage than they usually receive.

Critics of horse race coverage often urge journalists to be more responsible, and to treat the campaign more like a debate about substance than a contest of strategy ${ }^{61}$ The critics point to surveys that show that many voters say that they prefer substance over strategy. But the responses probably reflect more of what voters think they should say (their own sincere ideals) than what they actually do (their own actual behavior). The media would not continue to present so much horse race coverage if so many in their audiences did not consume it. ${ }^{62}$ But if we continue to try to lecture the media, we should at least direct the criticism against a more

precise target. We should encourage horse race coverage that provides information relevant to assessing the candidates in a balanced way and discourages the coverage that does not. Focus not on what makes the horses run, but on what the race shows about the character of the horses and their trainers.

\section{Debates As TESTS OF CHARACTER}

In general election campaigns, televised debates probably do not usually change most voters' preferences. ${ }^{63}$ Views about who won a debate are largely shaped by prior preferences. Debates may increase the political knowledge of the less informed but have less effect on the well 
informed. ${ }^{64}$ Still, a survey of 18 studies of recent debates concludes that they have some significant effects, especially on the salience of issues. ${ }^{65}$ Although the evidence about their effects in primary campaigns is more limited, it is reasonable to assume that they are more influential than those in the general election because the candidates differ less on the issues and primary voters are more attentive. ${ }^{66}$ There is, moreover, some evidence that primary debates significantly effect voters' judgment about the character of the candidates (though the studies define "character" more broadly than used here).$^{67}$ Primary debates may be an underappreciated tool for assessing constitutional character. Properly designed and skillfully moderated, they can expose differences in candidates' attitudes toward the democratic process especially by showing how they treat one another in a confrontational setting. The explicit comparisons that are possible when candidates face one other before a common audience bring out differences in the way they deal with challenges, controversies, and personal insults.

In recent years, the debates in both parties have featured all the candidates - often as many as eight at each event. This bountiful offering does not create the most conducive format for encouraging a sustained discussion of the issues or for showing substantive differences between the leading candidates. Some observers therefore favor a debate limited to the top contenders more like the debates in the general election. It is certainly true that differences in positions on issues cannot be pursued in any depth when so many candidates try to participate in the discussion. Raising your hand in response to a question from the moderator - an extreme but symptomatic technique used in 2007 - does not provide much enlightenment. ${ }^{68}$ Nevertheless, if we recognize that the more important question in a primary is not the difference between candidates on issues but the differences in their constitutional character, we might find a more populous forum preferable. It enables candidates to demonstrate how well they can deal with challenges from a wider range of opponents. Because constructive engagement with the opposition is an indicator of a capability for cooperation, the multicandidate debate is often a more revealing test than a format with only two or three candidates.

This does not mean that the candidates themselves should ignore issues. Even without themselves following the substance of the discussion in depth, viewers can tell whether the candidates are taking the issues seriously, speaking candidly, taking responsibility for their past statements, and displaying other similar qualities that bear on constitutional character. Even voters who do not take the issues seriously may still insist that their nominee does.

Another reason that candidates must try to engage in genuine deliberation about issues relates more to the development of the candidates' character than the voters assessment of it. In this respect, the value of the debate is less to inform citizens than to enlighten the candidates. We might say that debates help some candidates learn what they believe. In the course of a series of debates, candidates refine their positions, find common ground, and improve their ability to justify their positions to diverse audiences. ${ }^{69}$ They modify their positions as they learn how to respond more effectively to the arguments of voters, both supporters and opponents. Just as the primary process facilitates voters' changing their views 
over time, so it can encourage candidates to do the same. Thus in the debates, there is a division of learning. Candidates deliberate so that they can learn more about the substance of the issues, but citizens observe so that they can learn more about the character of the candidates. The candidates learn about issues while the voters learn about the candidates.

\section{CONCLUSION}

The scholarly study and political commentary about the presidential primary process has proceeded with little analysis of the principles of democratic theory. Criticisms of the process and proposals for reform presuppose those principles, yet the critics and the reformers seldom pause to examine what the principles mean, which are most important, and which may be neglected. Consequently, not only are some important normative issues slighted, but empirical inquiry misses some interesting problems. A case in point is the problem on which I have focused here - the potential of the nominating process to enable assessments of the character of the candidates. I have suggested that the process can be more democratic not primarily by encouraging more participation or competition, but by giving voters greater opportunities to judge the democratic commitments of the candidates.

When we ask how the process helps citizens judge the character of candidates (and how it can help candidates develop their character), we see the process in a different light in several ways. First, and most generally, voters, candidates and journalists are encouraged to pay attention to decisions and practices in the campaign that are relevant to assessing candidates but tend to be otherwise neglected. That is a useful corrective even if the primary process is remains more or less the same. Second, when we consider possible reforms, we can discover new reasons for supporting changes that some reformers already favor for different reasons. The case for a sequential compared to a simultaneous primary is further strengthened by noticing that it provides more and better opportunities for voters to learn about a candidate's constitutional character. Third, even if one believes on other grounds the case is already strong enough, the character-based considerations can influence the particular form the sequential primary should take. The intervals between each primary should be great enough, and the whole process long enough, to permit both voters and candidates to learn more about constitutional character. Fourth, a character-based perspective puts some controversies in a different light. The dispute about superdelegates and the seating of delegates from wayward states can be viewed not merely as an episode of strategic maneuvering or not even as a problem of deciding which democratic principle should prevail. How the candidates handle the dispute itself - whether they find ways to resolve it for the good of the party, for example - can be taken as a test of character. Finally, looking at the process from the perspective of constitutional character can directly challenge some conventional criticisms. For example, horse race coverage turns out to be more valuable than is commonly assumed.

Debates may be seen not so much as occasions for voters to learn what candidates think about 
the issues but more as opportunities for voters to observe how candidates deal with disagreement, and whether they themselves learn from the experience.

Primaries can be proving grounds for candidates to show their commitment to the democratic process, or lack thereof. In this respect, primaries may be even more important than general elections. In general election campaigns, partisan commitments and underlying predispositions more strongly shape voters' attitudes, and strategic imperatives more nearly determine the candidates' responses. In primary campaigns, the dynamic possibilities of the political process can be more effectively exploited. Candidates have more opportunities to show their constitutional character in response to changing circumstances in a series of contests. Voters can be more open to changing their judgments of candidates' character in response to fresh revelations. General elections can test character too. But primaries are the last clear chance to select candidates who show a firm commitment to the democratic process - a commitment that citizens, whatever their partisan persuasions, should demand from their presidents, whatever their party. Our nominating process should be designed to enable citizens to seize that chance, and help them choose the best nominees, which after all should be the primary purpose of primaries.

\section{NOTES}

1. Caroline Tolbert and Peverill Squire, "Reforming the Presidential Nomination Process," PS: Political Science ơ Politics 42 (January 2009): 27-32 at 27-28.

2. Marty Cohen, David Karol, Hans Noel, and John Zaller, The Party Decides: Presidential Nominations Before and After Reform (Chicago: University of Chicago Press, 2008), 360.

3. Quoted by Austin Ranney, Curing the Mischiefs of Faction (Berkeley: University of California Press, 1975), 124-25.

4. V. O. Key, Jr., Politics, Parties, and Pressure Groups, $5^{\text {th }}$ ed. (New York: Thomas Y. Crowell, 1964), 395. Key immediately adds: "While a change in the system of making nominations does not eliminate the function of the organized minority in leading party opinion, it may enable a different minority to prevail."

5. E. E. Schattschneider, Party Government (Westport, CT: Greenwood Press, 1942), 60. For more recent statement in this tradition, expressing concern that the "legitimate role of organized leadership" has been pushed aside by "simple minded calls for 'more democracy,' " see Chrisopher Achen and Larry Bartels, "Tumblling Down into a Democratical Republick," Prepared for presentation at the Annual Meeting of the Midwest Political Science Association, Chicago, April 12-15, 2007,1-43 at 16,33).

6. Henry Jones Ford “The Direct Primary," North American Review 190 (July 1909), 1-14 at 2, emphasis added.

7. E.g. Key, Politics, 395; Achen and Bartels, “Tumblling Down," 10; and Cohen et al., The Party Decides, 4. 
8. Jean Jacques Rousseau, The Social Contract, (Harmondsworth: Penguin, 1968), Bk. I, chs. 6-7, 59-64; Bk. III, ch. 1, 101-07, Bk. II, chs. 3-4, 72-78; Bk. IV ch. 2, 151-54.

9. Tolbert and Squire, "Reforming," 29.

10. Dennis F. Thompson, Restoring Responsibility (Cambridge: Cambridge University Press, 2005), 227-42.

11. Dennis F. Thompson, "Constitutional Character: Virtues and Vices in Presidential Leadership," Presidential Studies Quarterly 40 (March 2010): 23-37.

12. Robert Dahl, Polyarchy: Participation and Opposition (New Haven: Yale University Press, 1972), 1-16.

13. Thompson, Restoring Responsibility, 11-49.

14. John H. Aldrich, "A Dynamic Model of Presidential Nomination Campaigns," American Political Science Review 74 (September 1980): 651-69; Larry Bartels, Presidential Primaries and the Dynamics of Public Choice (Princeton, NJ: Princeton University Press, 1988); and Aldrich, "The Invisible Primary and Its Deleterious Effects on Democratic Choice," PS: Political Science 42 (January 2009): 33-38.

15. Cohen et al., The Party Decides, 303-04. But the selection of Obama and McCain in 2008 is an "empirical challenge to the thesis of party revival and control" in Jack Citrin and David Karol, "Introduction," in Citrin and Karol, eds., Nominating the President: Evolution and Revolution in 2008 and Beyond (Lanham MD: Rowman and Littlefield, 2009), 20.

16. Ibid., 304 .

17. Bartels, Presidential Primaries, 309-10.

18. Bruce E. Altschuler, "Selecting Presidential Nominees by National Primary," The Forum 5 (2008): 1-19.

19. Elsewhere I have argued for simultaneous voting in general elections in part because they are "final" and binding on all citizens, but suggested that in primaries other considerations may outweigh the value of simultaneity. See Thompson, "Electoral Simultaneity: Expressing Equal Respect,” Journal of Social Issues 64 (September 2008): 487-501.

20. Elaine Kamarck, Primary Politics (Washington: Brookings, 2009), 174-79.

21. Rebecca B. Morton and Kenneth C. Williams, "Information Asymmetries and Simultaneous versus Sequential Voting," American Political Science Review 93 (March 1999)5167; Steven Callander, "Bandwagons and Momentum in Sequential Voting," Review of Economic Studies 74 (2007): 653-84; Randall E Adkins and Andrew J. Dowdle, "How Important Are Iowa and New Hampshire to Winning Post-Reform Presidential Nominations?" Political Research Quarterly, 54 (June 2001): 431-444.

22. Bartels, Presidential Primaries, 101.

23. Ibid., 107.

24. Kamarck, Primary Politics, 38-39. 
25. William G. Mayer and Andrew E. Busch, The Front-Loading Problem in Presidential Nominations (Washington: Brookings, 2004); and Mayer, "An Incremental Approach to Presidential Nomination Reform,” PS: Political Science 42 (January 2009): 65-69.

26. Andrew E. Busch, "Assumptions and Realities of Presidential Primary Front-Loading," in Citrin and Karol, Nominating the President, 92.

27. Cohen et al., The Party Decides, 10.

28. Bartels, Presidential Primaries, 289-93.

29. Sam Stein, “Obama Camp's Memo on Clintons' Politicizing Race," Huffington Post (January 12 2008). http://www.huffingtonpost.com/2008/01/12/obama-camps-memo-onclint_n_81205.html.

30. Beth LaMontagne, "When Simple Mistakes Go Bad: Presidential campaigns already racking up the gaffes," Politics (Campaigns o' Elections) 28 (September 2007): 14-15.

31. Transcript, Democratic Debate, Las Vegas (January 15, 2008), Council on Foreign Relations, http://www.cfr.org/publication/15274).

32. Josh Gerstein, "Obama on Daschle: I take responsibility" Politico (February 3, 2009) http://www.politico.com/news/stories/0209/18344.html.

33. Robert E. DiClerico and James W. Davis, Choosing Our Choices: Debating the Presidential Nominating Procesd (Lanham MD: Rowman and Littlefield, 2000), 39-40.

34. Mayer, “An Incremental Approach,” 68.

35. Altschuler, "Selecting Presidential Nominees,"9-10.

36. Christopher Hull, Grassroot Rules: How the Iowa Caucus Helps Elect American Presidents (Stanford: Stanford University Press, 2007).

37. Michael Lewis-Beck and Peverill Squire, "Iowa: The Most Representative State?" PS: Political Science 42 (January 2009): 39_44.

38. Bella M. DePaulo, James J. Lindsay, Brian E. Malone, Laura Muhlenbruck, Kelly Charlton and Harris Cooper, "Cues to Deception," Psychological Bulletin 129 (2003): 74-118; and Vrij Aldert, Detecting Lies and Deceit: Pitfalls and Opportunities, $2^{\text {nd }}$ ed. (Malden MA: WileyInterscience, 2008).

39. Kamarck, Primary Politics, 178. The plan was first proposed by Robert D. Loevy, The Flawed Path to the Presidency: unfairness and Inequality in the Presidential Selection Process (Albany: State University of New York Press, 1992).

40. Kevin Esterling, Michael Neblo and David Lazer, "Means, Motive and Opportunity in Becoming Informed about Politics: A Deliberative Field Experiment," Paper presented at the annual meeting of the American Political Science Association, Chicago, IL, Aug 30, 2007 $<$ http://www.allacademic.com/meta/p211854_index.html>. Hull finds that because the Iowa process puts a high premium on strong grassroots networks, the effects seem to to amplify the impact of the internet - what he calls "e-mentum" (Hull, Grassroots Rules). 
41. Generally, see Kamarck, Primary Politics, 155-65; and William G. Mayer, "Superdelegates: Reforming the Reforms Revisited," in Steven S. Smith and Melanie J. Springer, eds., Reforming the Presidential Nomination Process (Washington: Brookings, 2009), 85-108.

42. Kamarck, Primary Politics, 156.

43. Ibid., 115-17, 160.

44. Salena Zito, "Burden of Poof," Pittoburgh Tribune-Review, (April 13, 2008), quoted by Kamarck, 163.

45. Kos [Markos Moulitsas], "The Rules," Daily Kos (March 25, 2008) at http://www.dailykos.com/storyonly/2008/3/25/131618/748/644/483450.

46. DiClerico and Davis, Choosing Our Choices, 18-19.

47. Delegate Selection Rules for the 2008 Democratic National Convention, Rule 12J and 11J (Washington: Democratic National Committee, August 19, 2006), 14.

48. Key, Politics, 411.

49. "DNC Democratic Change Commission Co-Chairs Statements On The Democratic Change Commission's Recommendations," December 30, 2009.

http://blog.4president.org/2012/2009/12/dnc-democratic-change-commission-cochairsstatements-on-the-democratic-change-commissions-recommenda.html

50. Delegate Selection Rules for the 2008 Democratic National Convention, Rule 20.C1 (Washington: Democratic National Committee, August 19, 2006), p. 20.

51. The "story of the modern nomination system" can be told by showing how presidential candidates "regard structure strategically, how they attempt to shape the system to their advantage..." (Kamarck, Primary Politics, 4).

52. David Mark, Going Dirty: The Art of Negative Campaigning (Lanham MD: Rowman and Littlefiled 2006), 205.

53. Steven A. Holmes, "After Campaigning on Candor, McCain Admits He Lacked it on Confederate Flag Issue,” New York Times, 20 April 2000.

54. Marion Just, Tami Buhr, and Ann Crigler,"Shifting the Balance: Journalist versus Candidate Communication in the 1996 Presidential Campaign," in Larry M. Bartels and Lynn Vavreck, eds., Campaign Reform (Ann Arbor: University of Michigan Press, 2000), 138; Bartels, "Campaign Quality: Standards for Evaluation, Benchmarks for Reform," in Bartels and Vavreck, 16; Larry M. Bartels et al., "Campaign Reform: Insights and Evidence: Report of the Task Force on Campaign Reform," in Bartels and Vavreck, 213-14. Notice, however, that the Task Force is careful to point out some benefits of horse-race coverage (215). A study of media coverage of primaries from 1912 through 2000 concluded that the tendencies to cover the primaries as a "dramatic conflict or horse race" and to focus on the personal traits of the candidate were present consistently throughout the period...not new in the age of television" (Kathleen E. Kendall, Communication in Presidential Primaries (Westport CT: Praeger, 2000), 204. 
55. The trend is world-wide, but more pronounced in the United States: Fritz Plasser and Gunder Plasser, Global Political Campaigning (Westport CT: Praeger, 2002), 71. The trend was temporarily reversed in the United States presidential campaign of 1996; because the outcome was so predictable, the press wrote more about substance: Just et al,"Shifting the

Balance,"138. Ironically, it seems that campaign discussion contains more substance when it is least likely to affect the outcome.

56. Stephen J. Farnsworth and S. Robert Lichter, "How Television Covers the Presidential Nomination Process," in William Mayer, ed., The Making of the Presidential Candidates 2008 (Lanham MD: Rowman and Littlefield, 2007) 79-80.

57. David Broder, “1980 GOP Presidential Field Is Already Crowded,” Washington Post, January 21, 1979, Al (quoted by Cohen et al., The Party Decides, 194).

58. Bartels, Presidential Primaries, 35.

59. Thomas Patterson, Out of Order (New York: Knopf, 1993), 20, 70; and Bartels et al., "Report of the Task Force,"214-15.

60. Patterson, ibid.; and Bartels, "Campaign Quality,"17-19, 54. Bartels notes that differential effects of "game schemas" compared to "policy schemas" in coverage during the campaign may be minimal, and that definitively distinguishing the separate effects of these types of coverage is not possible.

61. E.g., Just et al., “Shifting the Balance," 138- 39.

62. Richard Johnston, Andre Blais, Henry Brady and Jean Crete, Letting the People Decide: The Dynamics of Canadian Elections (Stanford University Press, 1992), 10-11.

63. Johnston et al., Letting the People Decide, 10-11, and the citations there.

64. Bartels et al, "Report of the Task Force," 241 n 17 . One study found that "candidate debates seem to reduce rather than increase prospective voters' knowledge of the candidates' issue stands" (Bartels, "Campaign Quality,"56).

65. William L. Benoit, Glenn J. Hansen and Rebecca M. Verser, "A meta-analysis of the effects of viewing U.S. presidential debates," Communication Monographs 70 (December 2003), 335-350.

66. Ibid., 347, 343-44; and William L. Benoit et al., The Primary Decision: A Functional analysis of Debates in Presidential Primaries (Westport CT: Praeger, 2002), 123-24, 131.

67. Benoit et al., “A Meta-analysis," 344, 346; and Kendall, Communication in Presidential Primaries, 88.

68. CNN, Transcripts, "New Hampshire Presidential Candidates Debate," June 3, 2007, available at http://transcripts.cnn.com/TRANSCRIPTS/0706/03/se.01.html.

69. Referring to how Obama learned from his poor performance at a candidate forum and other joint appearances, David Axelrod observed that "It took a while to figure out how to swim...As bright and as gifted as he is...he went through a period that was very difficult...Little by little he began to learn the rhythm and the pace and the requirements." [Dan Balz and Haynes Johnson, The Battle for America 2008 (New York: Viking 2009), 74]. 